Int. J. Dev. Biol. 57: 517-523 (2013)

doi: $10.1387 / \mathrm{ijdb} .130176 \mathrm{~mm}$

\title{
High-throughput analysis of rice genes by means of the heterologous full-length cDNA overexpressor (FOX)-hunting system
}

\author{
MIEKO HIGUCHI-TAKEUCHI ${ }^{1}$ MASAKI MORI ${ }^{2}$ and MINAMI MATSUI*,1,3 \\ ${ }^{1}$ RIKEN Center for Sustainable Resource Science, Yokohama, Kanagawa, Japan, ${ }^{2}$ Disease Resistance Crops Research and \\ Development Unit, National Institute of Agrobiological Sciences, Tsukuba, Ibaraki, Japan and ${ }^{3}$ Biomass Engineering Program \\ Cooperation Division, RIKEN Center for Sustainable Resource Science, Yokohama, Kanagawa, Japan
}

\begin{abstract}
Mutant populations are indispensable tools for investigating plant gene functions. Gain-of-function technology is one of the approaches used for the systematic production of mutant resources and activation tagging is a well-established method to generate gain-of-function mutants in plants. As an alternative approach for the systematic generation of a gain-of-function mutant population, we developed the Full-length cDNA OvereXpressor (FOX)-hunting system in which full-length cDNAs (fl-cDNAs) are overexpressed in plants to quickly identify candidate genes. The FOX-hunting system was used for high-throughput analysis of rice (Oryza sativa) genes heterologously expressed in Arabidopsis thaliana (rice FOX Arabidopsis lines). A large screening to identify and characterize rice genes with rice FOX Arabidopsis lines revealed that one of the isolated genes, BROAD-SPECTRUM RESISTANCE 1 (BSR1) conferred multiple or broad-spectrum disease resistance in both a dicotyledonous and monocotyledonous plant. We found that expression of rice fl-cDNAs without a homolog in Arabidopsis affected morphological traits. In addition, overexpression of homologous genes of rice and Arabidopsis led to a similar phenotype. Thus, we conclude that the FOX-hunting system is an excellent heterologous system and offers a new tool with which to explore gene function in rice.
\end{abstract}

KEY WORDS: full-length cDNA, rice, Arabidopsis, gain-of-function

\section{Introduction}

Arabidopsis thaliana (L;) Heyhn. is the first higher plant of which the genome has been sequenced (Kaul et al., 2000). As the sequencing technology has progressed, the genomes of many other plant species have been determined (for a review, see Mochida and Shinozaki, 2010). Whereas Arabidopsis is very much the model dicotyledonous plant, rice (Oryza sativa) has been selected as the model monocotyledonous plant. In the meantime, the rice genome has been sequenced (Matsumoto et al., 2005) of which, to date, the quality is similar quality to that of Arabidopsis. Since the completion of the genome sequencing, researchers have focused on understanding the gene functions and the signaling networks involved in development and response to environmental changes. Functional genomics has become an important tool in the post-sequencing era to describe the biological function of every gene products. Research tools, such as transcriptome (Rensink and Buell, 2005), proteome (Agrawal and Rakwal, 2011) and computational annotation (Ouyang et al., 2007; Tanaka et al., 2008), have been created to understand gene functions in rice. These studies enabled us to analyze functionally rice genes on a large scale. In addition, biological resources have been developed for gene function identification. More than 28,000 full-length cDNAs (fl-cDNAs) of rice have been collected (Kikuchi et al., 2003). Mutant collections are other useful resources and high-throughput screens using these mutant populations should provide a means to analyze plant gene functions.

Some of the most important mutant resources are loss-offunction mutants, because their phenotypes are often the best clue to understand gene functions (Hirochika, 2001; Kuromori et

Abbreviations used in this paper: BSR1, BROAD-SPECTRUM RESISTANCE 1 gene; CaMV, Cauliflower mosaic virus; fl-cDNA, full-length cDNA; FOX, full-length cDNA overexpressor; TMV, tobacco mosaic virus.

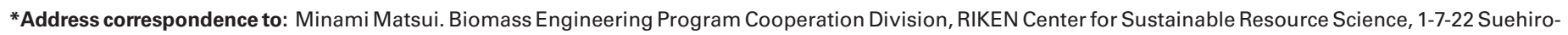
cho, Tsurumi-ku, Yokohama, Kanagawa 230-0045 Japan. Tel: +81-45-503-9585. Fax: +81-45-503-9584. E-mail: minami@ riken.jp
} 
al., 2009). Large sets of loss-of-function mutant resources of rice are available, including natural variations and artificial mutants caused by chemically induced mutagenesis, Tos 17 transposon, and T-DNA insertional mutagenesis (for a review, see Hirochika et al., 2004). Besides loss-of-function mutants, gain-of-function mutants are alternative resources (Kondou et al., 2010). In rice, approximately 10,000 genes are grouped into families (Tanaka et al., 2008). When functionally redundant paralogous genes of the gene of interest occur in the genome, its function is difficult or impossible to uncover with a knockout approach. Therefore, gain of function can complement a loss-of-function approach when redundant members of gene families are analyzed.

The classical approach for generating a gain-of-function mutant population in plants is the activation tagging system. This method has been developed by using transcriptional enhancers, such as the Cauliflower Mosaic Virus 35S (CaMV 35S), to activate genes located proximally to the T-DNA or transposon insertion sites. We have developed an original gain-of-function mutagenesis method, designated Full-length cDNA OvereXpressing (FOX)-hunting system. In this system, fl-cDNAs are used for ectopic gene expression in plants. In this review, we describe two types of gain-of-function approaches and investigate a gene function in rice through analysis of these mutant resources.

\section{Activation tagging in rice}

Activation tagging, a well-established technology for generating gain-of-function mutants in plants, has been used for more than 10 years. A T-DNA-containing enhancer sequence is randomly introduced into the plant genome where it boosts the expression of adjacent genes (Weigel et al., 2000). In rice, activation-tagging lines have been constructed since 2002 (Jeong et al., 2002) and several groups have created more than 150,000 lines in total by using different activation-tagging vectors. From these lines, valuable genes have been identified (for a review, see Zhang et al., 2009; Tsuchida-Mayama et al., 2010; Lee et al., 2011), but in most cases, multimeric CaMV 35 S enhancers are used.
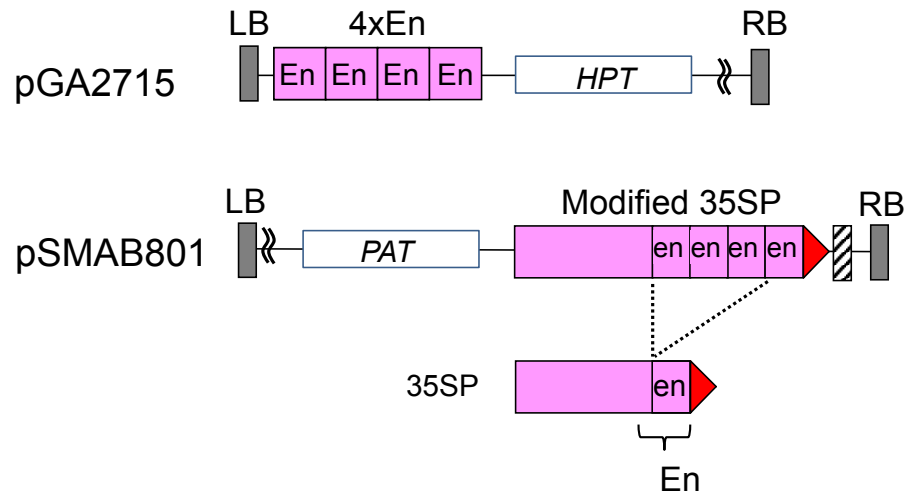

Fig. 1. Schematic representation of a traditional and a modified activation-tagging vector pGA2715 and pSMAB801, respectively. Abbreviations: En, CaMV 35 S enhancer element (-417 to -86); en, CaMV $35 S$ enhancer element (-287 to -91); HPT, hygromycin phosphotransferase gene; PAT, phosphinothricin acetyltransferase gene; $L B$, left border sequence; $R B$, right border sequence; 35SP, CaMV 35S promoter; pink box, 5 '-upstream sequence of CaMV 35 S minimum promoter; red triangle, CaMV $35 S$ minimum promoter; hatched box, first intron of the phaseolin gene.
Although pGA2715 is typical activation-tagging vector in rice (Jeong et al., 2002) (Fig. 1), a modified activation-tagging vector, pSMAB801, has been developed that contains a CaMV 355 promoter with tetrameric enhancers (Mori et al., 2007) (Fig. 1). Generally, in a vector, such as pGA2715, the -417 to -86 upstream region of the CaMV $35 S$ promoter is used as the enhancer element and tetramerized (Weigel et al., 2000; Jeong et al., 2002), but, because the -287 to -91 region has a stronger enhancer effect in rice protoplasts, this shortened region is utilized as the enhancer in pSMAB801. In addition, a CaMV 35 S minimum promoter and the phaseolinfirst intron have been placed downstream of the tetramerized enhancers to activate flanking genes more strongly (Fig. 1).

Approximately 13,000 activation-tagging rice lines were generated using pSMAB801 and many morphological mutants were obtained. Spotted leaf 18 (Sp/18) and Short grain 1 (Sg1) were mutants isolated by visual screening (Mori et al., 2007; Nakagawa et al., 2012). In Spl18, overexpression of a new acyltranferase gene (OsAT1) induced a lesion-mimicking and disease resistance phenotype (Mori et al., 2007). In Sg1, overexpression of the novel gene, SG1, induced a phenotype of short grains and dwarfing, reminiscent of brassinosteroid-deficient mutants. In contrast, knockdown rice plants that down-regulated both $S G 1$ and a related gene SG1-LIKE PROTEIN1 (SGL1) had longer grains (Nakagawa et al., 2012). Both SPL18 and SG1 genes are specific genes for monocots and have homologs in rice. Therefore, the functions of these genes would not have been identified easily without using a gain-of-function approach.

\section{FOX-hunting system}

Although activation tagging is a very valuable tool for the generation of gain-of-function mutants, the overexpression effect depends on the insertion site of the T-DNA or transposable element. In addition, CaMV $35 S$ enhancers can influence the activation of genes up to several kb from the insertion site (Hsing et al., 2007), thereby, in some cases, complicating the identification of the genes responsible for the observed phenotypes.

To overcome these problems, a different approach has been developed to systematically generate gain-of-function mutants, the FOX-hunting system (Ichikawa et al., 2006) (Fig. 2). As fl-cDNAs contain all the information for the production of functional RNAs and proteins, they were expressed to obtain gain-of-function mutations. With this system, approximately 10,000 fl-cDNAs obtained from the RIKEN Arabidopsis fl-cDNA collection (Seki et al., 2002) were used to generate Arabidopsistransgenic plants. Each fl-cDNA was mixed at approximately the same molar ratio and cloned into an expression vector. To facilitate the translation initiation, $\Omega$ sequences of the Tobacco Mosaic Virus (TMV) were included into the expression vector. Expression constructs harboring the fl-cDNAs were transformed with Agrobacterium tumefaciens and, in turn, the Agrobacterium library to engineer Arabidopsis plants in planta. $\mathrm{T}_{1}$ plants expressing individual fl-cDNAs were self-pollinated and the $\mathrm{T}_{2}$ seeds were harvested. These transgenic plants are the Arabidopsis FOX lines and approximately 23,000 were obtained. The introduced fl-cDNA(s) can be identified quickly with vector-specific primers and, thus, the fl-cDNAs and their effects as transgenes can be analyzed easily.

On average, approximately $2.6 \mathrm{fl}-\mathrm{cDNAs}$ were introduced into each Arabidopsis FOX line and 1,487 morphological mutants were 
TABLE 1

\section{SOME OF THE RICE GENES FUNCTIONALLY CHARACTERIZED THROUGH THE RICE FOX ARABIDOPSIS LINES}

\begin{tabular}{|c|c|c|c|}
\hline Gene Name & Function/Description & Phenotype & Reference \\
\hline OsHsfA2e & Heat stress transcription factor & Heat stress tolerant & Yokotani et al. (2008) \\
\hline OsNACO63 & NAC transcription factor & Salt stress tolerant & Yokotani et al. (2009b) \\
\hline OsSMCP1 & Small protein with a single $\mathrm{C} 2$ domain, a $\mathrm{Ca}^{2+}$-dependent membrane-targeting domain. & Salt stress tolerant & Yokotani et al. (2009a) \\
\hline OsLBD37 & Lateral organ boundaries domain & Metabolite & Albinsky et al. (2010) \\
\hline OsCEST & Unknown & Salt stress tolerant & Yokotani et al. (2011) \\
\hline BSR1 & Putative receptor-like cytoplasmic kinase & Resistance to rice blast & Dubouzet et al. (2011) \\
\hline FNR1/FNR2 & Ferredoxin $\mathrm{NADP}^{+}$-oxidoreductase & Photosynthesis & Higuchi-Takeuchi et al. (2011) \\
\hline Jamyb & R2R3-type MYB transcription factor & Salt stress tolerant & Yokotani et al. (2013) \\
\hline
\end{tabular}

found in 15,547 lines (Ichikawa et al., 2006). Many different mutants were screened, including those in chloroplast development (Okazaki et al., 2009), organ size (Breuer et al., 2009), carbon and nitrogen responses (Sato et al., 2009), trehalose resistance (Delatte et al., 2011), and brassinosteroid response (Schneider et al., 2012). Thus, the FOX-hunting system and the genetic lines are invaluable resources for high-throughput analysis of gene function in Arabidopsis.

\section{FOX rice lines}

To analyze rice genes, the FOX-hunting system was used by overexpressing rice fl-cDNAs (Nakamura et al., 2007) and appoximately 12,000 lines were generated in which 13,980 independent $\mathrm{fl}$-cDNAs were overexpressed. Various visible phenotypes were observed in the $\mathrm{T}_{0}$ generation, involving changes in cell and tissue proliferation, organ morphology, plant height, growth habit, heading date, and seed fertility. Approximately $16.6 \%$ of these FOX rice lines showed altered growth or morphological characteristics. The observed phenotype could be reproduced by retransformation of the introduced fl-cDNA into rice and one dwarf mutant was characterized that was caused by overexpression of a novel gibberellin 2-oxidase gene (Nakamura et al., 2007). By means of these FOX rice lines, green calli overexpressing the Golden2-like transcription factor (OsGLK1) were isolated and chloroplast development was demonstrated to be regulated by OsGLK1 (Nakamura et al., 2009). In addition, a mutant with increased plant height and seed size overexpressing the TIFY gene (TIFY11b) was identified and shown to increase its grain size by carbohydrate accumulation (Hakata et al., 2012).

\section{Rice FOX Arabidopsis lines}

The advantage of heterologous gene expression is that it is possible to analyze gene function by using another plant species as

Fig. 2. Schematic representation of the FOX-hunting system. The cDNA library is cloned into the expression vector and an Agrobacterium library carrying fl-cDNAs is generated. The Agrobacterium library is used to introduce the fl-cDNAs into Arabidopsis and generate $T_{1}$ seeds. $T_{1}$ plants are self-pollinated to generate $T_{2}$ seeds. The $T_{2}$ seeds can be used for several types of screening. The introduced CDNA is isolated from the candidate FOX line and the fl-cDNA responsible for the observed phenotype is determined. Abbreviations: E1, 5'-upstream sequence of the CaMV $35 S$ promoter (-419 to -90); 35S, CaMV 35 S promoter; $\Omega$, translation enhancer of TMV; Ter, nopaline synthase terminator; $L B$, left border sequence; $R B$, right border sequence. a host. Arabidopsis is one of the best host plants, because a very efficient, fast, and high-throughput transformation system has been developed. Therefore, we utilized Arabidopsisas the host plant and rice as the heterologous fl-cDNA resource for functional analysis of rice genes. A rice fl-cDNA expression library was generated with approximately 13,000 independent rice fl-cDNAs. From this library, more than 33,000 independent Arabidopsis transgenic lines (rice FOX Arabidopsis lines) expressing rice fl-cDNAs were obtained (Kondou et al., 2009). Several screening types were performed with these rice FOX Arabidopsis lines to isolate putative mutants with alterations in a range of phenotypes, including morphology, photosynthesis, metal element and pigment accumulation, hormone profiles, secondary metabolites, pathogen resistance, salt tolerance, UV signaling, high-light tolerance, and heat stress tolerance

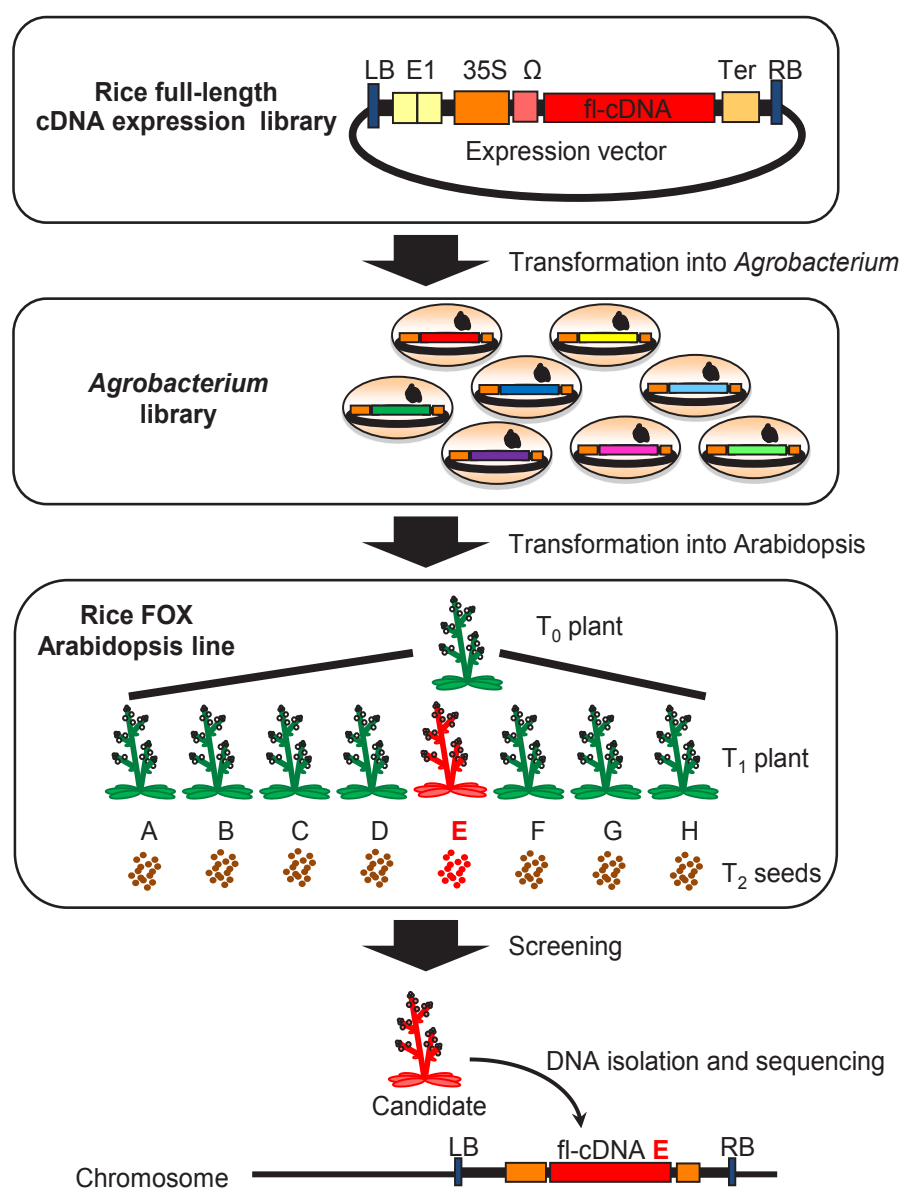


(Kondou et al., 2009). The screening results are available through the website (http://ricefox.psc.riken.jp; Sakurai et al., 2011). The functions of several rice genes investigated with the rice FOX Arabidopsis lines are summarized in Table 1.

Flanking sequence tag analysis in transformed rice has been developed to discover the biological function of particular genes by means of a reverse genetics approach (for reviews, see An et al., 2003; Hirochika et al., 2004). To obtain information about the transferred fl-cDNAs of the rice FOX Arabidopsis, the fl-cDNAs of 18,547 rice FOX Arabidopsis lines were amplified by polymerase chain reaction and sequenced. The sequence analysis provided $6,501 \mathrm{fl}-\mathrm{cDNAs}$ from $13,018(70.2 \%)$ of the tested lines, of which 3,309 fl-cDNAs were identified in more than two lines. The flcDNA information is available in the rice fl-cDNA overexpressed Arabidopsis mutant database (http://ricefox.psc.riken.jp; Sakurai et al., 2011).

Abnormal morphological phenotypes were observed in the $T_{1}$ generation of 1,122 lines, of which 199 phenotypes reappeared in the $T_{2}$ generation, indicating that they were hereditary and not caused by environmental conditions. Of the 199 lines, we determined the fl-cDNAs in 172 lines, from which 182 fl-cDNAs were identified. Phenotypic analysis revealed that expression of 11 rice $\mathrm{fl}$-cDNAs resulted in the same phenotype in more than two lines, suggesting that they were responsible for the mutant phenotypes. Of these, four proteins encoded by the fl-cDNAs (Os03g0142900, Os03g0184100, Os10g0546400, and Os03g0822400) were of unknown function. Interestingly, only eight fl-cDNAs have homologous genes in Arabidopsis.

\section{Disease resistance gene isolated from rice FOX Arabidopsis lines}

Broad-spectrum disease resistance against two or more types of pathogen species is desirable for crop improvement, but only a few genes have been identified until now. In rice, two of the most devastating pathogens are Xanthomonas oryzae pv. oryzae (Xoo), the causal bacterium of rice leaf blight, and Magnaporthe oryzae, the fungal pathogen of rice blast. To find rice genes conferring broad-spectrum disease resistance, rice FOX Arabidopsis lines were used because the small size and short lifespan of Arabidopsis enable high-speed and large-scale screening. Approximately 20,000 of the transgenic lines were screened for bacterial disease resistance against $P$ seudomonas syringae pv. tomatoDC3000 (Pst DC3000). Pst DC3000 was selected not only because it is a widely used bacterium in Arabidopsis research, but also exhibits a type III secretion mechanism for infection, which is similar to that of Xoo. Arabidopsis is generally inoculated with Pst DC3000 by dipping or infiltration and the resistance level is evaluated by bacterial counts or lesion size in the infected plants. However, these conventional protocols are difficult to apply to 20,000 lines. Hence, the following high-throughput disease resistance screening system was developed. The rice FOX Arabidopsis lines were grown in 60-well plates for 3 weeks under aseptic conditions, dip inoculated with PstDC3000, incubated, and evaluated for resistance in a binomial way (survive or die). After three rounds of independent screens, 72 lines that showed constant resistance were selected and the identities of the transgenes were determined. Most of the identified genes (including their orthologs in other species) had not been previously associated with resistance to any disease (Dubouzet et al., 2011). Next, these 72 lines were screened for resistance to the fungal pathogen Colletotrichum higginsianum that had been chosen because it infects Arabidopsis by forming appressoria and penetration pegs, a process similar to that by which $M$. oryzae infects rice. Thirteen lines out of these 72 were also resistant to C. higginsianum and 11 causal genes were identified.

Several rice genes that conferred resistance to both PstDC3000 and C. higginsianum in Arabidopsis were transformed into rice. The transformants were evaluated for their resistance to the rice bacterial pathogen, Xoo. One of the transgenic rice was highly resistant to $X o O$ and, interestingly, this line also showed high resistance to $M$. oryzae (Fig. 3). Therefore, the causal rice gene encoding a putative receptor-like cytoplasmic kinase was designated BROAD-SPECTRUMRESISTANCE 1(BSR1) (Dubouzet et al., 2011). The resistance given by the $B S R 1$ gene is outstanding, because it confers multiple or broad-spectrum disease resistance to both bacterial ( $P$. syringae and $X$. oryza) and fungal pathogens (C. higginsianum and $M$. oryzae) in dicotyledonous and monocotyledonous plants. To our knowledge, no other such disease-resistant monocotyledonous gene has been reported so far.

The BSR1 protein sequence is similar to that of the Arabidopsis BOTRYTIS-INDUCED KINASE1 (BIK1), it is not an orthologue. $\mathrm{BIK} 1$ is a receptor-like cytoplasmic kinase that has recently been shown to associate with pathogen-associated molecular pattern (PAMP) receptor complexes (such as the flagellin-sensitive2/ brassinosteroid insensitive1 (BRI1)-associated receptor kinase1) mediate PAMP-triggered immunity signal transduction from multiple PAMP receptor complexes by phosphorylation. BSR1, like BIK1, is supposed to function by linking multiple PAMP receptor complexes to downstream intracellular signaling, in view of the broad-spectrum disease resistance of $B S R 1$ observed in both Arabidopsis and rice (Dubouzet et al., 2011).

A
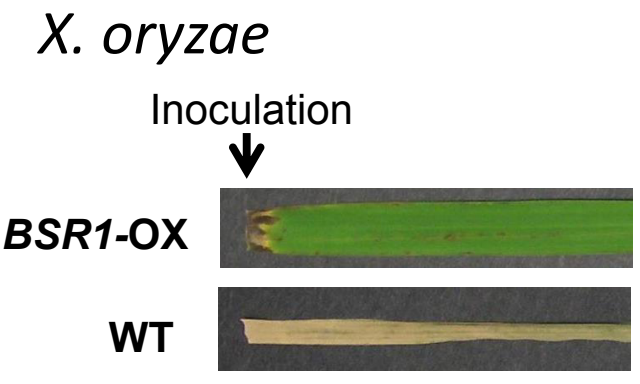

B

\section{M. oryzae}

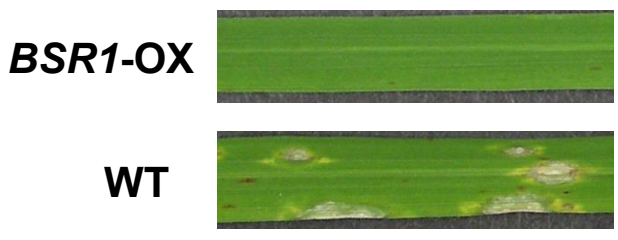

Fig. 3. Disease resistance of transgenic rice. Transgenic rice overexpressing BSR1 shows resistance to the bacterial pathogen Xanthomonas oryzae pv. oryzae (A) and the fungal pathogen Magnaporthe oryzae (B) An arrow indicates the point of inoculation. Abbreviations: BSR1-ox, BSR1 overexpressor; WT, wild type. 
Thus, the rice FOX Arabidopsis lines are very useful as a tool for the functional analysis of genes. Furthermore, the presence of common defense mechanisms between monocots and dicots has been proposed.

\section{Phenotype of Arabidopsis plants expressing rice- specific full length cDNAs}

We could determine $182 \mathrm{fl}-\mathrm{cDNAs}$ in the rice FOX Arabidopsis lines that showed morphological phenotypes in the $T_{2}$ generation as previously described. Detailed information for these $182 \mathrm{fl}$-cDNAs was obtained by using the KOME database (http://cdna01.dna.affrc. go.jp/cDNA/). The analysis indicated that 152 of the $182 \mathrm{fl}-\mathrm{cDNAs}$ had Arabidopsis homologs. Of the 30 remaining rice-specific flcDNAs, three provoked a similar morphological phenotype in two independent lines (Fig. 4A), indicating that they were candidates for inducing the mutant phenotypes. Interestingly, the functions of all three, Os10g0546400, Os03g0822400 and Os02g0180800, are unknown. Os10g0546400, which is predicted to encode a 129-amino-acid protein of unknown function, was found in two rice FOX Arabidopsis lines, both of which showing notched rosette and cauline leaves. The predicted protein encoded by Os $10 \mathrm{~g} 0546400$ is conserved in monocotyledonous plants only (purple false brome [Brachypodium distachyon], sorghum [Sorghum bicolor], maize [Zea mays], and barley [Hordeum vulgare]). Os03g0822400, encoding a conserved hypothetical protein of 90 amino acids was recovered from two rice FOX Arabidopsis lines that also showed notched rosette and cauline leaves and is conserved in monocots only. Os02g0180800, which is annotated as a nonprotein-coding transcript, was inserted into two independent lines that both had a greatly increased number of dark-green leaves. Part of its sequence is conserved in maize and barley. These three examples indicate that heterologous genes are expressed and can be functional in different plant species. Systematic heterologous expression can be useful introduce improvements into plants that cannot be achieved by conventional genetic methods.

\section{Phenotypic comparison between rice FOX Arabidopsis lines and Arabidopsis FOX lines}

We have reported that 1,487 morphological mutants were observed in Arabidopsis FOX lines overexpressing Arabidopsis fl-cDNAs (Ichikawa et al., 2006). These lines have been sequenced for the transferred fl-cDNAs. We investigated whether overexpression of homologous genes in rice and Arabidopsis led to similar phenotypes. In the first example, two FOX lines with an altered leaf morphology (Fig. 4B) contained the fl-cDNAs Os08g0566400 (rice) and $A t 4 g 28706$ (Arabidopsis). The predicted amino acid sequences of these two genes showed $66 \%$ identity. The InterProScans of the predicted proteins of the two genes correlated with ribokinase, which participates in the first step of ribose metabolism, and is a member of the carbohydrate kinase superfamily. These results indicate that functional orthologous genes can be detected through database screening of two sequence libraries.

Another example involves the two isoforms of ferredoxin NADP ${ }^{+}$ oxidoreductase (OsFNR1 and OsFNR2) (Higuchi-Takeuchi et al., 2011) that catalyzes the reduction of NADP+ by ferredoxin and provides the reducing power for $\mathrm{CO}_{2}$ fixation in the Calvin cycle in chloroplasts. There is approximately $80 \%$ sequence identity at the amino acid level between the Arabidopsis and the rice FNR. Expression of rice fl-cDNAs of the FNR isoforms led to a similar phenotype of altered chlorophyll fluorescence and growth in both Arabidopsis and rice.

A third example is the ATP-dependent caseinolytic protease (CIp) family that is involved in chloroplast development (Olinares et al., 2011). Expression of two rice fl-cDNAs of the Clp family (Os12g0230100 and Os03g0308100) caused a pale-green phenotype, whereas in one Arabidopsis FOX line a pale-green phenotype was provoked by overexpression of the CIpR2 fl-cDNA (At1g12410) (Fig. 4C). These results suggest that FNR and Clp protease of rice and Arabidopsis can serve the same function in both species.

Comparison of the rice FOX Arabidopsis lines and Arabidopsis FOX lines resulted in the discovery of three homologous genes that showed common phenotypes, although 152 homologous gene pairs were identified in the rice FOX Arabidopsis lines and Arabidopsis FOX lines. Hence, in many cases, the overexpression of homologous and orthologous genes might induce different phenotypes and might indicate that a sequence ortholog is not necessarily a functional ortholog and that orthologous proteins cannot exert their function due to interaction specificity with other proteins.

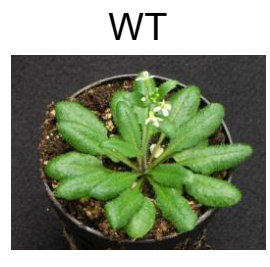

A

Rice specific genes
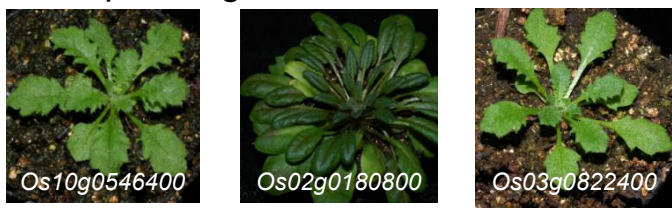

B Ribokinase
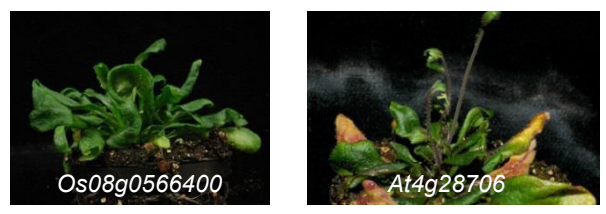

C Clp protease family
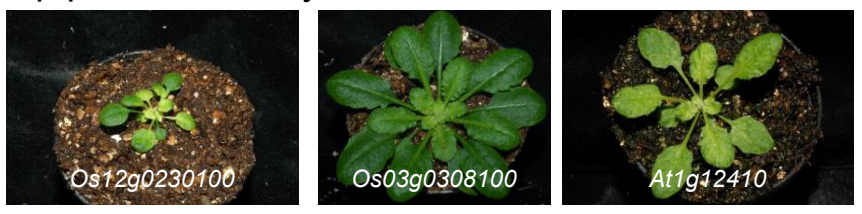

Fig. 4. Morphological mutants isolated from FOX lines. (A) Ricespecific genes, from left to right, Os10g0546400, Os02g0180800, and Os03g0822400, expressed in Arabidopsis plants. (B) Introduction of ribokinase, from left to right, of Os08g0566400 and AT4G28706. (C) Introduction of the Clp protease family, from left to right, of the rice ATP-binding subunit clpA homolog (Os12g0230100), the rice peptidase S14, the ClpP family protein (Os03g0308100) and the Arabidopsis ClpP protease complex subunit ClpR2 (At1g12410). 


\section{Outlook}

The FOX-hunting system can have many applications. To elucidate salt-stress responses, mini-scale FOX lines expressing 29 of the calcium-dependent protein kinase (CDPK) family were generated in rice (Asano et al., 2010). They were screened for salt-stress resistance and salt-stress tolerant transformants overexpressing OsCPK12 were identified. Of the many gene families in rice, the functions of most are still unknown. Undoubtedly, through the FOXhunting approach, the function of a gene family can be clarified.

Heterologous approaches have been used in several plants with the Agrobacterium library. The Arabidopsis FOX Agrobacterium library was transformed into a supergrowing root culture of the legume Lotus corniculatus to identify genes involved in root growth (Himuro et al., 2011). Some of these transformants showed useful traits, such as fast growth and thicker and longer roots. Thus, the FOX Agrobacterium library is a new biological resource for genetic analysis.

Recently, a chemical genomics approach has been developed to facilitate the understanding of gene function. By means of Arabidopsis FOX lines, overexpression of two enzymes involved in pectin modulation (pectin methylesterase and polygalacturonase) conferred resistance to cobtorin, an inhibitor of parallel alignment of cortical microtubules and cellulose microfibrils (Yoneda etal., 2010).

Afunctional genomics approach is required to clarify the function of genes in many crop species other than rice. However, transgenic approaches for both forward and reverse genetics studies are not practical in plant species in which the transformation method is inefficient or not available. By using Arabidopsisor other transformable plants as a host plant, rapid gene function analysis of such plants will become possible after fl-cDNA preparation.

\section{Acknowledgements}

We would like to thank Drs. Takanari Ichikawa and Hirofumi Kuroda for valuable help, discussion, and comments and Ms. Yoko Horii and Mr. Satoru Maeda for technical support. This work was supported by Grantsin-aid for Scientific Research of the Japanese Society for the Promotion of Science (no. 23580142 to M.M. and no. 24580098 to M.H.), and the program for Promotion of Basic and Applied Research for Innovations in Bio-oriented Industry (to M.H.).

\section{References}

AGRAWAL G K, RAKWAL R (2011). Rice proteomics: A move toward expanded proteome coverage to comparative and functional proteomics uncovers the mysteries of rice and plant biology. Proteomics 11: 1630-1649.

ALBINSKY D, KUSANO M, HIGUCHI M, HAYASHI N, KOBAYASHI M, FUKUSHIMA A, MORI M, ICHIKAWA T, MATSUI K, KURODA H, HORII Y, TSUMOTO Y, SAKAKIBARA H, HIROCHIKA H, MATSUI M, SAITO K (2010). Metabolomic screening applied to rice FOX Arabidopsis lines leads to the identification of a genechanging nitrogen metabolism. Mol Plant 3: 125-142.

AN S, PARK S, JEONG D-H, LEE D-Y, KANG H-G, YU J-H, HUR J, KIM S-R, KIM $\mathrm{Y}-\mathrm{H}$, LEE M et al. (2003). Generation and analysis of end sequence database for TDNA tagging lines in rice. Plant Physiol 133: 2040-2047.

ASANO T, WAKAYAMA M, AOKI N, KOMATSU S, ICHIKAWA H, HIROCHIKA H, OHSUGI R (2010). Overexpression of a calciumdependent protein kinase gene enhances growth of rice under lownitrogen conditions. Plant Biotechnol27:369-373.

BREUER C, KAWAMURAA, ICHIKAWAT, TOMINAGA-WADAR, WADA T, KOUDOU Y, MUTO S, MATSUI M, SUGIMOTO K (2009). The trihelix transcription factor GTL1 regulates ploidydependent cell growth in the Arabidopsis trichome. Plant Cell 21: 2307-2322.

DELATTE T L, SEDIJANI P, KONDOU Y, MATSUI M, DE JONG G J, SOMSEN G
W, WIESEKLINKENBERG A, PRIMAVESI L F, PAUL M J, SCHLUEPMANN H (2011). Growth arrest by trehalose6phosphate: an astonishing case of primary metabolite control over growth by way of the SnRK1 signaling pathway. Plant Physiol 157: 160-174.

DUBOUZET J G, MAEDA S, SUGANO S, OHTAKE M, HAYASHI N, ICHIKAWA T, KONDOUY, KURODAH, HORIIY, MATSUIM, ODAK, HIROCHIKAH, TAKATSUJI H, MORI M (2011). Screening for resistance against Pseudomonas syringae in riceFOX Arabidopsis lines identified a putative receptorlike cytoplasmic kinase gene that confers resistance to major bacterial and fungal pathogens in Arabidopsis and rice. Plant Biotechnol J 9: 466-485.

HAKATA M, KURODA M, OHSUMI A, HIROSE T, NAKAMURA H, MURAMATSU M, ICHIKAWAH, YAMAKAWAH (2012). Overexpression of a rice TIFY gene increases grain size through enhanced accumulation of carbohydrates in the stem. Biosci Biotechnol Biochem 76: 2129-2134.

HIGUCHITAKEUCHI M, ICHIKAWA T, KONDOU Y, MATSUI K, HASEGAWA Y, KAWASHIMAM, SONOIKE K, MORIM, HIROCHIKAH, MATSUIM (2011). Functional analysis of two isoforms of leaftype ferredoxinNADP+oxidoreductase in rice using the heterologous expression system of Arabidopsis. Plant Physiol 157: 96-108.

HIMUROY, TANAKAH, HASHIGUCHIM, ICHIKAWAT, NAKAZAWAM, SEKI M, FUJITA M, SHINOZAKI K, MATSUI M, AKASHI R, HOFFMANN F (2011). FOXsuperroots of Lotus corniculatus, overexpressing Arabidopsis fullength cDNA, show stable variations in morphological traits. J Plant Physiol 168: 181-187.

HIROCHIKA H (2001). Contribution of the Tos17 retrotransposon to rice functional genomics. Curr Opin Plant Biol 4: 118-122.

HIROCHIKAH, GUIDERDONI E, AN G, HSING Y-I, EUN M Y, HAN C-D, UPADHYAYA N, RAMACHANDRAN S, ZHANG Q, PEREIRAA, SUNDARESAN V, LEUNG H (2004). Rice mutant resources for gene discovery. Plant Mol Biol 54: 325-334.

HSING Y-I, CHERN C-G, FAN M-J, LU P-C, CHEN K-T, LO S-F, SUN P-K, HO S-L, LEE K-W, WANG Y-C et al. (2007). A rice gene activation/knockout mutant resource for high throughput functional genomics. Plant Mol Biol 63: 351-364.

ICHIKAWA T, NAKAZAWA M, KAWASHIMA M, IIZUMI H, KURODA H, KONDOU Y, TSUHARA Y, SUZUKI K, ISHIKAWA A, SEKI M, FUJITA M, MOTOHASHI R, NAGATA N, TAKAGI T, SHINOZAKI K, MATSUI M (2006). The FOX hunting system: an alternative gainoffunction gene hunting technique. Plant $J$ 48: 974-985.

JEONG D-H, AN S, KANG H-G, MOON S, HAN J-J, PARK S, LEE H S, AN K, AN G (2002). TDNA insertional mutagenesis for activation tagging in rice. Plant Physiol 130: 1636-1644.

KAUL S, KOO H L, JENKINS J, RIZZO M, ROONEY T, TALLON L J, FELDBLYUM T, NIERMAN W, BENITO M.I, LIN X et al. (2000). Analysis of the genome sequence of the flowering plant Arabidopsis Thaliana. Nature 408: 796-815.

KIKUCHIS, SATOHK, NAGATAT, KAWAGASHIRAN, DOIK, KISHIMOTON, YAZAKI J, ISHIKAWA M, YAMADA H, OOKA H et al. (2003). Collection, mapping, and annotation of over 28,000 cDNA clones from japonica rice. Science 301: 376379 [Err. 301, 1849].

KONDOU Y, HIGUCHI M, TAKAHASHI S, SAKURAI T, ICHIKAWA T, KURODA H, YOSHIZUMI T, TSUMOTO Y, HORII Y, KAWASHIMA M et al. (2009). Systematic approaches to using the FOX hunting system to identify useful rice genes. Plant J 57: 883-894.

KONDOUY, HIGUCHI M, MATSUI M (2010). Highthroughput characterization of plant gene functions by using gainoffunction technology. Annu Rev Plant Biol61:373-393.

KUROMORI T, TAKAHASHI S, KONDOU Y, SHINOZAKI K, MATSUI M (2009). Phenome analysis in plant species using lossoffunction and gainoffunction mutants. Plant Cell Physiol 50: 1215-1231.

LEE S, PERSSON D P, HANSEN T H, HUSTED S, SCHJOERRING J K, KIM Y-S, JEON U S, KIM Y-K, KAKEI Y, MASUDA H, NISHIZAWA N K, AN G (2011). Bioavailable zinc in rice seeds is increased by activation tagging of nicotianamine synthase. Plant Biotechnol J 9: 865-873.

MATSUMOTO T, WU J, KANAMORI H, KATAYOSE Y, FUJISAWA M, NAMIKI N, MIZUNO H, YAMAMOTO K, ANTONIO B A, BABA T et al. (2005). The mapbased sequence of the rice genome. Nature 436: 793-800.

MOCHIDAK, SHINOZAKIK (2010). Genomics and bioinformatics resources for crop improvement. Plant Cell Physiol 51: 497-523.

MORI M, TOMITA C, SUGIMOTO K, HASEGAWA M, HAYASHI N, DUBOUZET J $\mathrm{G}, \mathrm{OCHIAI} \mathrm{H,} \mathrm{SEKIMOTO} \mathrm{H,} \mathrm{HIROCHIKA} \mathrm{H,} \mathrm{KIKUCHI} \mathrm{S} \mathrm{(2007).} \mathrm{Isolation} \mathrm{and}$ molecular characterization of a Spotted leaf 18 mutant by modified activationtagging in rice. Plant Mol Biol 63: 847-860. 
NAKAGAWA H, TANAKAA, TANABATA T, OHTAKE M, FUJIOKA S, NAKAMURA H, ICHIKAWA H, MORI M (2012). SHORT GRAIN1 decreases organ elongation and brassinosteroid response in rice. Plant Physiol 158: 1208-1219.

NAKAMURA H, HAKATA M, AMANO K, MIYAO A, TOKI N, KAJIKAWA M, PANG J, HIGASHI N, ANDO S, TOKI S, FUJITA M, ENJU U A, SEKI M, NAKAZAWA M, ICHIKAWA T, SHINOZAKI K, MATSUI M, NAGAMURA Y, HIROCHIKA H, ICHIKAWA H (2007). A genomewide gainof function analysis of rice genes using the FOXhunting system. Plant Mol Biol 65: 357-371.

NAKAMURAH, MURAMATSU M, HAKATAM, UENO O, NAGAMURAY, HIROCHIKA $\mathrm{H}$, TAKANO M, ICHIKAWA H (2009). Ectopic overexpression of the transcription factor OsGLK1 induces chloroplast development in nongreen rice cells. Plant Cell Physiol 50: 1933-1949.

OKAZAKI K, KABEYA Y, SUZUKI K, MORI T, ICHIKAWA T, MATSUI M, NAKANISHI H, MIYAGISHIMA S-Y (2009). The PLASTID DIVISION1 and 2 components of the chloroplast division machinery determine the rate of chloroplast division in land plant cell differentiation. Plant Cell 21: 1769-1780.

OLINARES P D B, KIM J, VAN WIJK K J (2011). The Clp protease system; a central component of the chloroplast protease network. Biochim Biophys Acta 1807: 999-1011.

OUYANG S, ZHU W, HAMILTON J, LIN H, CAMPBELL M, CHILDS K, THIBAUDNISSEN F, MALEK R L, LEE Y, ZHENG L, ORVIS J, HAAS B, WORTMAN J, BUELL C R (2007). The TIGR Rice Genome Annotation Resource: improvements and new features. Nucleic Acids Res 35: D883-D887.

RENSINK A W, BUELL C R (2005). Microarray expression profiling resources for plant genomics. Trends Plant Sci 10: 603-609.

SAKURAI T, KONDOU Y, AKIYAMA K, KUROTANI A, HIGUCHI M, ICHIKAWA T, KURODAH, KUSANO M, MORI M, SAITOU T et al. (2011). RiceFOX: A database of Arabidopsis mutant lines overexpressing rice fulllength cDNA that contains a wide range of trait information to facilitate analysis of gene function. Plant Cell Physiol 52: 265-273.

SATO T, MAEKAWAS, YASUDAS, SONODAY, KATOHE, ICHIKAWAT, NAKAZAWA M, SEKI M, SHINOZAKI K, MATSUI M, GOTO D B, IKEDA A, YAMAGUCHI J (2009). CNI1/ATL31, a RINGtype ubiquitin ligase that functions in the carbon/ nitrogen response for growth phase transition in Arabidopsis seedlings. Plant $J$ 60: 852-864.

SCHNEIDER K, BREUER C, KAWAMURAA, JIKUMARUY, HANADAA, FUJIOKAS, ICHIKAWA T, KONDOU Y, MATSUI M, KAMIYA Y, YAMAGUCHI S, SUGIMOTO $\mathrm{K}$ (2012). Arabidopsis PIZZA has the capacity to acylate brassinosteroids. PLoS ONE 7: e46805.
SEKI M, NARUSAKA M, KAMIYAA, ISHIDAJ, SATOU M, SAKURAIT, NAKAJIMAM, ENJU A, AKIYAMA K, OONO Y et al. (2002). Functional annotation of a fulllength Arabidopsis cDNA collection. Science 296: 141145.

TANAKA T, ANTONIO B A, KIKUCHI S, MATSUMOTO T, NAGAMURA Y, NUMA H, SAKAI H, WU J, ITOH T, SASAKI T et al. (2008). The Rice Annotation Project Database (RAPDB): 2008 update. Nucleic Acids Res 36: D1028-D1033.

TSUCHIDAMAYAMA T, NAKAMURA H, HAKATA M, ICHIKAWA H (2010). Rice transgenic resources with gainoffunction phenotypes. Breed Sci 60: 493-501.

WEIGEL D, AHN J H, BLÁZQUEZ M A, BOREVITZ J O, CHRISTENSEN S K, FANKHAUSERC, FERRÁNDIZC, KARDAILSKYI, MALANCHARUVILE J, NEFF M M etal. (2000). Activation tagging in Arabidopsis. Plant Physiol122: 1003-1013.

YOKOTANI N, HIGUCHI M, KONDOU Y, ICHIKAWA T, IWABUCHI M, HIROCHIKA H, MATSUI M, ODA K (2011). A novel chloroplast protein, CEST induces tolerance to multiple environmental stresses and reduces photooxidative damage in transgenic Arabidopsis. J Exp Bot 62: 557-569.

YOKOTANI N, ICHIKAWA T, KONDOU Y, MATSUI M, HIROCHIKA H, IWABUCHI M, ODAK (2009b). Tolerance to various environmental stresses conferred by the saltresponsive rice gene ONAC063in transgenic Arabidopsis. Planta229: 1065-1075.

YOKOTANI N, ICHIKAWA T, KONDOU Y, IWABUCHI M, MATSUI M, HIROCHIKA $\mathrm{H}$, ODA K (2013). Role of the rice transcription factor JAmyb in abiotic stress response. J Plant Res 126: 131-139.

YOKOTANI N, ICHIKAWA T, KONDOU Y, MAEDA S, IWABUCHI M, MORI M, HIROCHIKA H, MATSUI M, ODA K (2009a). Overexpression of a rice gene encoding a small C2 domain protein OsSMCP1 increases tolerance to abiotic and biotic stresses in transgenic Arabidopsis. Plant Mol Biol 71: 391-402.

YOKOTANI N, ICHIKAWA T, KONDOU Y, MATSUI M, HIROCHIKA H, IWABUCHI $\mathrm{M}$, ODA K (2008). Expression of rice heat stress transcription factor OsHsfA2e enhances tolerance to environmental stresses in transgenic Arabidopsis. Planta 227: 957-967.

YONEDA A, ITO T, HIGAKI T, KUTSUNA N, SAITO T, ISHIMIZU T, OSADA H, HASEZAWAS, MATSUI M, DEMURA T (2010). Cobtorin target analysis reveals that pectin functions in the deposition of cellulose microfibrils in parallel with cortical microtubules. Plant J 64: 657-667.

ZHANG L-Y, BAI M-Y, WU J, ZHU J-Y, WANG H, ZHANG Z, WANG W, SUN Y, ZHAO J, SUN X, YANG H, XU Y, KIM S-H, FUJIOKA S, LIN W-H, CHONG K, LU T, WANG Z-Y (2009). Antagonistic HLH/bHLH transcription factors mediate brassinosteroid regulation of cell elongation and plant development in rice and Arabidopsis. Plant Cell 21: 3767-3780. 


\section{Further Related Reading, published previously in the Int. J. Dev. Biol.}

\section{Plant microRNAs and development}

Sara Jover-Gil, Héctor Candela and María-Rosa Ponce

Int. J. Dev. Biol. (2005) 49: 733-744

Balance between cell division and differentiation during plant development Elena Ramirez-Parra, Bénédicte Desvoyes and Crisanto Gutierrez

Int. J. Dev. Biol. (2005) 49: 467-477

From phenotypic to molecular polymorphisms involved in naturally occurring variation of plant development

Carlos Alonso-Blanco, Belén Mendez-Vigo and Maarten Koornneef

Int. J. Dev. Biol. (2005) 49: 717-732

Gene network analysis in plant development by genomic technologies

Frank Wellmer and José Luis Riechmann

Int. J. Dev. Biol. (2005) 49: 745-759

Mechanisms of the proliferation and differentiation of plant cells in cell culture systems H Fukuda, M Ito, M Sugiyama and A Komamine

Int. J. Dev. Biol. (1994) 38: 287-299

5 yr ISI Impact Factor $(2011)=2.959$
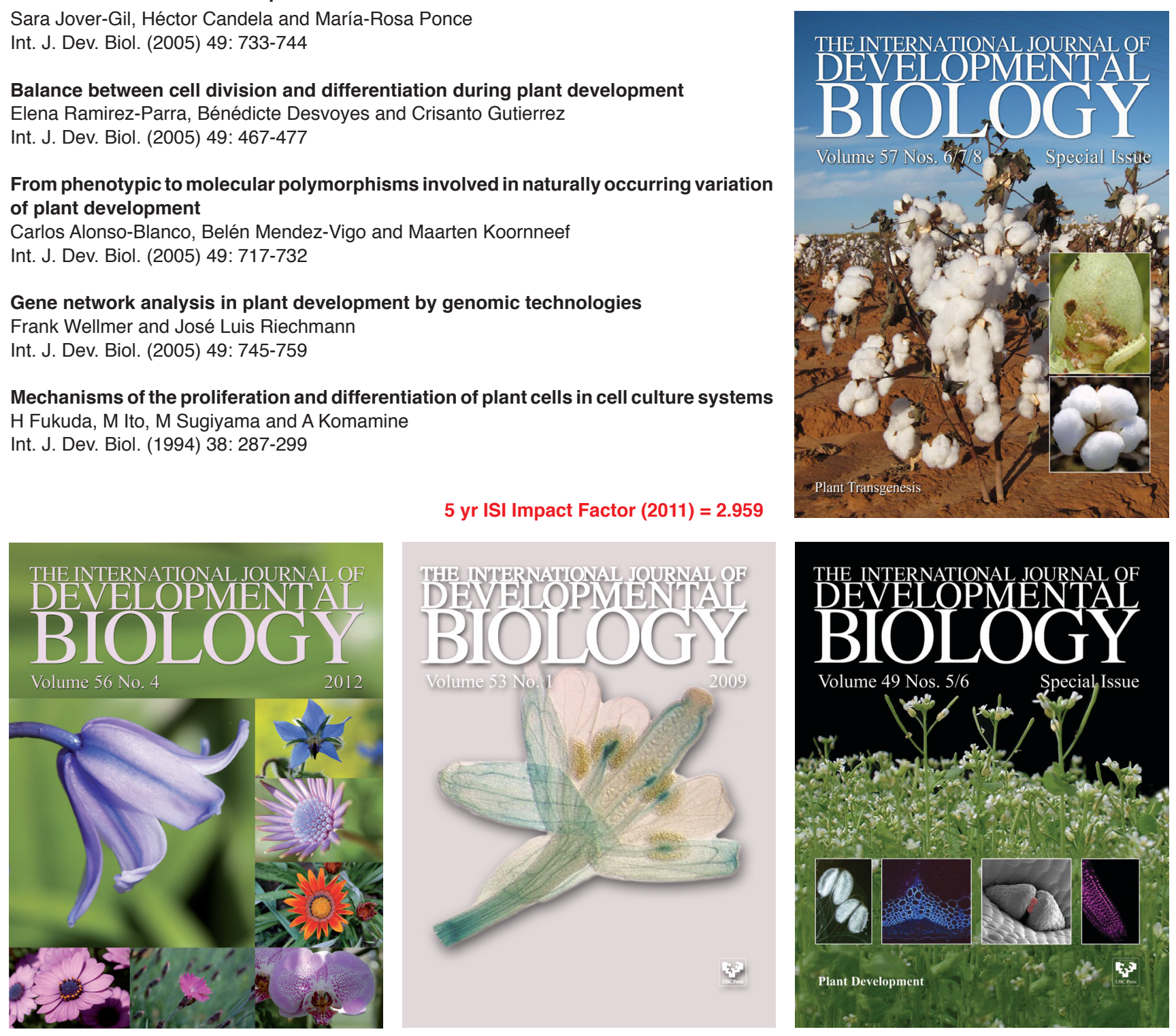